\title{
AMPA-Receptor GluRI Subunits are Involved in the Control Over Behavior by Cocaine-Paired Cues
}

\author{
Andy N Mead ${ }^{1,3}$, Daniel Zamanillo ${ }^{2,4}$, Nadine Becker ${ }^{1,5}$ and David N Stephens ${ }^{1, *}$ \\ 'Department of Psychology, School of Life Sciences, University of Sussex, Falmer, Brighton, UK; ${ }^{2}$ Max-Planck-Institute for Medical Research, \\ Heidelberg, Germany
}

\begin{abstract}
The learning processes underlying the formation of drug-cue associations involve changes in synaptic transmission mediated by AMPA receptors. Here, we examine the consequences of targeted deletion of the gene encoding GluRI subunits of AMPA receptors (grial knockouts $(\mathrm{KO})$ ) on cocaine self-administration and on the ability of cocaine-paired cues to affect cocaine-seeking in mice. Cocaine selfadministration was unaffected by grial deletion, as was the ability of a cocaine-paired cue to reinstate responding following extinction, following either a 3 or a 66 day delay. However, grial KOs over-responded during extinction. The KOs were unable initially to learn a new response to access a cue previously conditioned to cocaine (conditioned reinforcement (CR)), although a second test 2 months later revealed that this was a transient deficit. These studies indicate that GluRI-containing AMPA-receptors are not involved in cocaine self-administration, cue-induced reinstatement of cocaine seeking, or incubation of the cocaine seeking response. In order to understand the specificity of the deficits in CR responding, a parallel study was performed with food reward. As with cocaine, there were no effects of grial deletion on food self-administration or cue-induced reinstatement, and KOs over-responded during extinction. However, even immediately after instrumental training for food, $\mathrm{KO}$ mice demonstrated responding for $\mathrm{CR}$, suggesting that the CR deficit observed with a cocaine cue is specific to drug reward. These data indicate that GluRI-containing AMPA receptors are important in stimulus reward learning, though the method of cue-reward association formation, the reward class, and the behavioral end point are critical variables in determining their involvement.
\end{abstract}

Neuropsychopharmacology (2007) 32, 343-353. doi: I 0. I 038/sj.npp. I 30 I045; published online 22 February 2006

Keywords: cocaine self-administration; AMPA receptor; reinstatement; conditioned reinforcement; extinction; incubation

\section{INTRODUCTION}

During the development of addiction, the brain adapts to drug-taking in many ways that result in the drug gaining control over behavior. This loss of control over drug taking is a hallmark of addictive behavior. Some of the neural adaptations that take place during the addictive process are direct responses to the drug (Ungless et al, 2001), while others reflect learning processes. An important aspect of drug-related learning is that environmental events (cues)

\footnotetext{
*Correspondence: Dr DN Stephens, Department of Psychology, School of Life Sciences, John Maynard Smith Building, University of Sussex, Falmer, Brighton BNI 9QG, UK, Tel: + 441273678638 , Fax: + 441273 678058, E-mail: d.stephens@sussex.ac.uk

${ }^{3}$ Current address: Merck, Sharp \& Dohme Neuroscience Research Centre, Terlings Park, Harlow, Essex, UK.

${ }^{4}$ Current address: Esteve, Parc Cientific, 08028 Barcelona, Spain.

${ }^{5}$ Current address: Max Planck Institute of Neurobiology, 82152 Martinsried, Germany.

Received 20 September 2005; revised I 4 December 2005; accepted 13 January 2006

Online publication: 17 January 2006 at http://www.acnp.org/citations/ Npp0 1 1 706050584/default.pdf
}

become associated with drug taking, and eventually are able to trigger craving and increase the probability of drug taking.

In common with other learning mechanisms, learning about the relationship between drugs and associated environmental cues is likely to depend upon neurobiological mechanisms of long-term potentiation and depression, during which the ability of synapses to transmit information is facilitated by the insertion into the postsynaptic density of glutamatergic AMPA receptors (Malinow and Malenka, 2002). It seems likely that such adaptations to drugs occur in several parts of the brain, each contributing in different ways to facilitation of drug-seeking behavior. Indeed, there is considerable evidence to indicate that repeated experience of cocaine results in time-dependent changes in the efficiency of transmission mediated by AMPA receptors in accumbens (Boudreau and Wolf, 2005; Pierce $e t a l, 1996$ ) as well as VTA (Fitzgerald et al, 1996), that contribute to drug-seeking behavior (Cornish and Kalivas, 2000; Suto et al, 2004).

Recent studies indicate that changes in the expression of the GluR1 subunit of AMPA receptors are associated with drug-seeking behavior (Sutton et al, 2003) and that experimenter- or self-administered cocaine may upregulate 
GluR1 expression in functionally relevant regions such as the amygdala or nucleus accumbens (Churchill et al, 1999; Grignaschi et al, 2004; Lu et al, 2005; Lu et al, 2003). Increased surface expression of GluR1 has also been reported to occur following dopamine receptor stimulation, suggesting a role for GluR1 trafficking in cocaine-induced maladaptive plasticity (Mangiavacchi and Wolf, 2004; Sun et al, 2005). GluR1-containing receptors are also implicated in the ability of environmental cues to maintain rewardseeking (Mead and Stephens, 2003), so that such upregulation may facilitate the ability of drug-cues to direct behavior.

In attempts to understand the neurobiological substrates of drug-cue learning, and the mechanisms underlying relapse to cocaine seeking, a number of animal models have been developed. Of these, a paradigm which has received increasing recognition is the cue-induced reinstatement model (de Wit and Stewart, 1981) (see See, 2002; See $e t$ al, 2003; Shaham et al, 2003, for recent reviews). This model involves extinguishing a previously-learned instrumental response-drug contingency, and subsequently assessing the ability of a drug-paired cue (CS) to reinstate responding, reflecting increased drug seeking behavior. Typically, reinstatement is achieved by making the presentation of the CS contingent on the operant response that had previously been used to achieve drug self-administration (Shaham et al, 2003), though noncontingent presentation of discrete or contextual cues has also been found effective in reinstating responding (Alleweireldt $e t$ al, 2001; de Wit and Stewart, 1981; Deroche-Gamonet et al, 2002). The neural mechanisms underlying cue-induced reinstatement of cocaine seeking are still not well defined, with a manipulation of many systems having effects on the behavior, though it is clear that both glutamatergic and dopaminergic systems play crucial roles (see Shaham et al, 2003; Kalivas and McFarland, 2003; Bossert et al, 2005 for recent reviews).

Several aspects of this model are likely to depend upon GluR1-containing AMPA receptors. Firstly, Self et al (2004) suggest increases in GluR1 subunit of AMPA receptors in nucleus accumbens shell take place following one week of extinction of drug-seeking behavior, and play an essential role in suppressing previously rewarded behaviors when they no longer result in obtaining drug. Secondly, the extinction-reinstatement paradigm has many similarities to models of conditioned reinforcement (CR), whereby performance of an operant response results in presentations of a reward-paired CS (Di Ciano and Everitt, 2004; Robbins, 1978). We have reported previously that mice lacking the GluR1 subunit of the AMPA-receptor (gria1 KO mice (Zamanillo et al, 1999)) display a selective deficit in responding for a food paired cue despite successfully learning about other aspects of the cue-reward association (Mead and Stephens, 2003). We suggested that the effects of GluR1 deletion on Pavlovian learning parallel effects of basolateral amygdala (BLA) lesions, though it is important to remember that in the global KO model, GluR1 expression is altered throughout the brain at each stage of development, and the consequences of this on neural function and development are not fully understood.

The first purpose of this study was to determine whether this deficit in CR was also observed with a cocaineassociated cue using a variation of the $\mathrm{CR}$ paradigm in which the Pavlovian CS is associated with self-administered cocaine. Secondly, because of the theoretical similarities between the CR and cue-induced reinstatement paradigms (Di Ciano and Everitt, 2004), we also investigated the ability of the cocaine-paired cue to reinstate drug-seeking behavior. For comparison purposes, a parallel study was performed in which the cue was paired with food-reward, allowing dissociations to be drawn directly between food and cocaine reward and associated cues, following selfadministration of the primary reward. The food-study contrasts with our previous work with food-reward which was based on Pavlovian conditioning of the CS-US association (Mead and Stephens, 2003). Finally, we examined behaviors over a range of cocaine-withdrawal periods, since it has been reported that the ability of a cue to reinstate drug seeking behavior may increase (incubate) during extended withdrawal (Grimm et al, 2001; Grimm et al, 2003), in keeping with clinical reports of increased craving for cocaine over the first several weeks of abstinence (Gawin and Kleber, 1986).

\section{METHODS}

All experiments were performed in standard mouse operant chambers (Med-Associates, Georgia, Vermont). Each chamber was equipped with two retractable levers (Med-Associates), a tone-generator (Med-Associates) and stimulus lights located above each lever. Two nose-poke detectors were introduced into the opposite panel for $\mathrm{CR}$ studies. WT and grial $\mathrm{KO}$ mice were individual housed under constant temperature $\left(21 \pm 2^{\circ} \mathrm{C}\right)$ and humidity $(50 \pm 10 \%)$ conditions. The light-phase of the dark-light cycle occurred from 0700 to 1900 . For cocaine studies, all testing took place between 1600 and 0800 , while for food studies, all testing occurred between 0800 and 1800 . Prior to the beginning of the experiment, mice were food-deprived in order to reduce their bodyweight to approximately $85 \%$ of free-feeding weights. For food studies, food restriction was maintained throughout the study.

\section{Cocaine Self-Administration}

The complete series of experiments used seven male wildtype (WT) and seven male gria1 KO (Zamanillo et al, 1999) littermate mice, weighing 28-38 g (WT mean 31.8 \pm 1.6 ; KO $32.5 \pm 1.2 \mathrm{~g}$, at the time of catheter implantation), bred at the University of Sussex from heterozygous parents obtained from PH Seeburg (MaxPlanck Institut für Molekulare Biologie, Heidelberg, Germany) which were initially trained to respond on a lever for $20 \mathrm{mg}$ food-pellets (Noyes, Sandown Scientific, Middlesex, UK). All animals proceeded through all stages of the study. During food training sessions, the active lever (ie the lever which, when pressed, resulted in food delivery) was alternated on an hourly basis, in order to ensure that no lever preferences occurred prior to cocaine self-administration. No cues were associated with presentation of food. Mice were deemed to have successfully acquired responding for food when they obtained over 200 reinforcers during a single $15 \mathrm{~h}$ session. Following food training, mice were given free access to food in their home cages before undergoing surgery, during which indwelling 
catheters were inserted into the jugular vein, as described previously (Highfield et al, 2002; Jackson et al, 1998). Following surgery mice were allowed to recover for $36 \mathrm{~h}$ before the first cocaine self-administration session. Mice were not food-deprived during the remainder of the experiment, and both food and water were freely available in the operant box during the overnight sessions.

During cocaine self-administration sessions, the activelever was randomly assigned, but remained constant for each mouse. Eight $16 \mathrm{~h}$ overnight sessions were subdivided into four $2 \mathrm{~h}$ self-administration phases, during which both levers were available, and four intervening $2 \mathrm{~h}$ pauses, during which the levers were retracted, and the mice could not obtain cocaine. During self-administration phases, responses on the active lever resulted in an infusion of $0.75-\mathrm{mg} / \mathrm{kg}$ cocaine (the unconditioned stimulus; US), and a 10 -s presentation of the conditioned stimulus (CS), consisting of two $1 \mathrm{~Hz}$ flashing stimulus lights, and a $2.9 \mathrm{kHz}$ tone $5 \mathrm{~dB}$ above background. Following each cocaine infusion, a 10-s time-out period occurred during which active lever responses were not reinforced. The number of infusions was limited to 20 per phase ( 80 per night) during the first three nights of cocaine selfadministration, in order to prevent overdose. Responses on the inactive lever were also recorded, but had no consequence.

\section{Extinction of the Cocaine-Reinforced Behavior}

Extinction of cocaine self-administration occurred during a $17 \mathrm{~h}$ session two days after the final cocaine session (day 2), during which responses on the active lever resulted in a saline infusion (of equal volume to cocaine-infusions during the previous phase). The CS was not presented during the extinction session, and responses on the inactive lever had no consequence Table 1.

\section{Conditioned Reinforcement}

Tests for CR were conducted on days 1 and 65 after the final cocaine self-administration session. During CR tests, the

Table I Summary of Grial Deletion Effects on Conditioned Responses to Cocaine or Food Cues

\begin{tabular}{|c|c|c|c|}
\hline Behavior & $\begin{array}{l}\text { Withdrawal } \\
\text { (days) }\end{array}$ & Cocaine & Food \\
\hline Self-administration & - & Normal & Normal \\
\hline Extinction & - & Increased initially & Increased initially \\
\hline \multirow{2}{*}{$\begin{array}{l}\text { Conditioned } \\
\text { reinforcement }\end{array}$} & I & Abolished & Normal \\
\hline & 65 & Enhanced & - \\
\hline \multirow{2}{*}{$\begin{array}{l}\text { Cue-induced } \\
\text { reinstatement }\end{array}$} & 3 & Normal & Normal \\
\hline & 66 & $\begin{array}{l}\text { Normal } \\
\text { (incubation) }\end{array}$ & - \\
\hline \multirow{2}{*}{$\begin{array}{l}\text { Spontaneous } \\
\text { reinstatement }\end{array}$} & 3 & Normal & - \\
\hline & 66 & Enhanced & - \\
\hline
\end{tabular}

levers were retracted, and the two nose-poke detectors inserted in the opposite panel. Responses into one of the nose-poke detectors resulted in the presentation of the CS (CR nose-poke), while responding in the other detector had no consequences (NCR nose-poke). It is important to note that this is a different instrumental response to the one required for cocaine self-administration. The CR nose-poke was randomly assigned for each mouse, but remained constant for tests on days 1 and 65. Responses into both nose-poke detectors were recorded during the entire $15 \mathrm{~h}$ session.

\section{Spontaneous and Cue-Induced Reinstatement}

Tests for cue-induced reinstatement occurred both 3 and 66 days following the final cocaine self-administration session. During the first $10 \mathrm{~h}$ of each test, conditions were the same as during extinction, except that the saline infusion was omitted (due to the lack of catheter patency during the second test). Responding during the first $3 \mathrm{~h}$ of this period was analyzed as a measure of spontaneous reinstatement. The first response on the active lever after this initial $10 \mathrm{~h}$ period initiated the cue-induced reinstatement test, during which responses on the active lever resulted in the presentation of the CS. Responses on the inactive lever had no consequence, and the test continued for $3 \mathrm{~h}$. Response rates during this period were compared to baseline response rates during the $3 \mathrm{~h}$ prior to the cueinduced reinstatement test.

\section{CR and Cue-Induced Reinstatement for a Food-Paired Cue}

In all, 17 experimentally naive WT and 15 male grial $\mathrm{KO}$ littermate mice were trained to respond on a lever for $20 \mathrm{mg}$ food-pellets. Responding on the active lever resulted in the presentation of a food pellet on an FR1 schedule, and a 10-s presentation of the conditioned stimulus (CS), consisting of two $1 \mathrm{~Hz}$ flashing stimulus lights, and a $2.9 \mathrm{kHz}$ tone $5 \mathrm{~dB}$ above background. Responding on the inactive lever was not reinforced. Food training continued for a total of 15 sessions each of 60-min.

One day following the final food-training session, acquisition of responding for $\mathrm{CR}$ was assessed. During the $\mathrm{CR}$ test, the levers were retracted, and two nose-poke detectors inserted in the opposite panel. Responses into one of the nose-poke detectors resulted in the presentation of the CS (CR nose-poke), while responding in the other detector had no consequences (NCR nose-poke). The CR nose-poke was randomly assigned for each mouse. Responses into both nose-poke detectors were recorded during the 60 -min session.

Following CR testing, the lever operant response was extinguished over the course of four $60-\mathrm{min}$ sessions. During extinction sessions, the levers were reintroduced into the chambers and the nose-poke detectors removed. Responses on both the active and inactive lever were without consequence. At 1 day following the final extinction session, the ability of the food-paired CS to reinstate responding was examined. This 60 -min session was identical to extinction sessions, except that each response on the active lever resulted in the presentation of the CS. 
Response rates during this session were compared with response rates during the fourth extinction session, in order to determine the ability of the cue to reinstate reward seeking.

A summary of the experimental design for both the cocaine and food studies is shown in Figure 1. It should be noted that the parameters for the cocaine and food studies differed slightly since the aim was not to directly compare the two reinforcers, but instead to assess cuelearning in both models. Given the inherent differences between food and cocaine (eg motivational value, consummatory activity etc), it would not be possible to ring identical studies for cocaine and food reward, and instead, conditions were optimized for the primary purpose of the experiments.

\section{Statistical Analysis}

All data were initially analyzed using mixed-factor ANOVA. Following significant interactions, further analysis was performed using ANOVA followed by Fisher PLSD tests where appropriate. Between-genotype comparisons were performed where appropriate following a significant main-

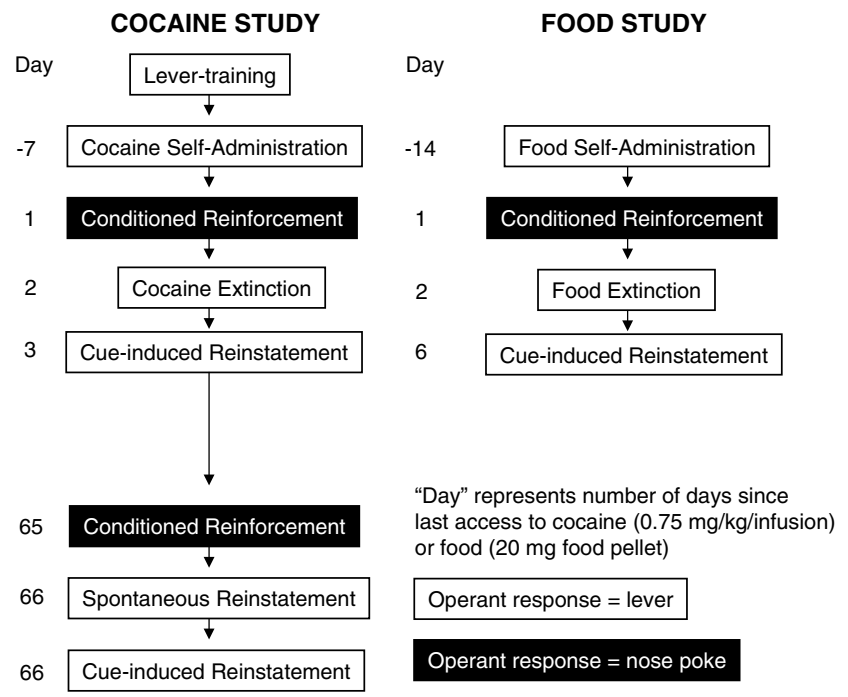

Figure I Experimental design summary. effect or interaction term, using an independent samples $t$ test. Where necessary, data were square root transformed in order to attain homogeneity of variance and permit valid parametric analysis.

\section{RESULTS}

\section{Cocaine Self-Administration}

Response rates decreased over the first two sessions, as typically observed with lever-trained mice. Within eight sessions both WT and grial KO mice acquired a lever-press response to initiate an infusion of $0.75-\mathrm{mg} / \mathrm{kg}$ cocaine (the unconditioned stimulus; US), accompanied by a 10-s presentation of the conditioned stimulus (CS), consisting of two $1 \mathrm{~Hz}$ flashing stimulus lights, and a $2.9 \mathrm{kHz}$ tone $5 \mathrm{~dB}$ above background (Figure 2). No differences were observed in the pattern of acquisition (Panel A, genotype by session interaction; $\left.\mathrm{F}_{7,84}=0.23, \mathrm{NS}\right)$ nor the total number of infusions obtained (main-effect of genotype; $F_{1,12}=1.56$, NS). Analysis of lever responses (Panel B) revealed that all mice selectively responded on the active lever (main-effect of lever, $\mathrm{F}_{1,12}=31.2, p<0.001$ ).

\section{Extinction of the Cocaine-Reinforced Behavior}

Figure 3 shows that replacement of cocaine with saline, and omission of the CS resulted in altered responding in both a genotype and a time-dependent manner (lever by genotype interaction; $\mathrm{F}_{1,11}=8.29, p<0.05$, and lever by time interaction; $\left.\mathrm{F}_{8.88}=2.57, p<0.05\right)$. Post hoc analysis indicated that there was a trend towards greater responding on the active lever in the grial $\mathrm{KO}$ mice during the first $4 \mathrm{~h}$ of the extinction session $\left(1-2 \mathrm{~h} ; t_{11}=2.04, p=0.07\right.$ and $3-4 \mathrm{~h}$; $\left.t_{11}=1.74, p=0.10\right)$. The apparent absence of an extinctionlike decline in responding in the WT mice may be attributable to the extinction period spanning the onset of the dark period of the light cycle.

\section{Conditioned Reinforcement}

When the mice were given the opportunity to perform a novel operant response (nose-poke) in order to obtain CS presentations, WT mice responded at higher rates into the aperture that resulted in the presentation of the CS, than
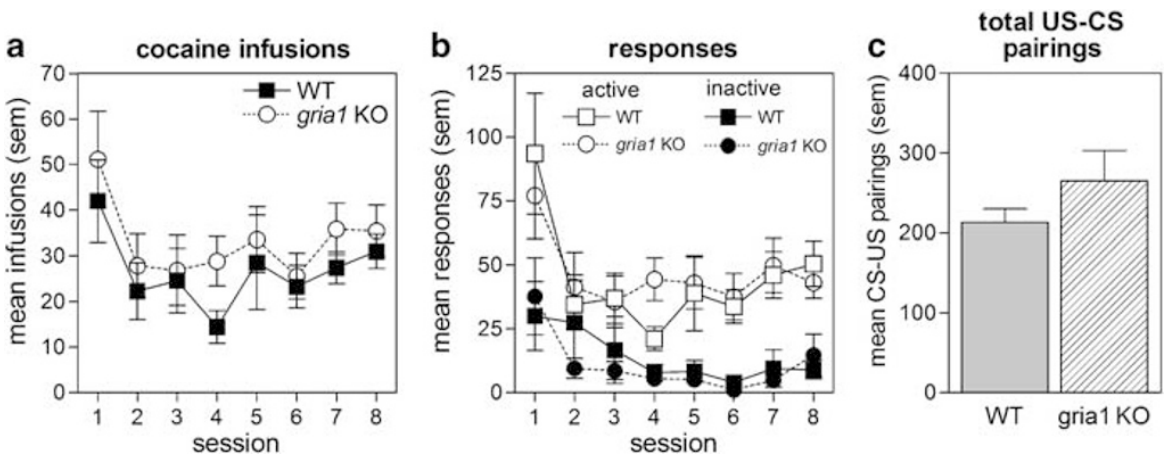

Figure 2 Cocaine self-administration in WT and grial $\mathrm{KO}$ mice. (a) Total infusions of $0.75 \mathrm{mg} / \mathrm{kg}$ cocaine earned during each session in WT (filled symbols) and grial KO (open symbols) mice. (b) Total active (open symbols) and inactive (closed symbols) lever presses during each session. (c) Total number of cue-cocaine associations experienced during the course of self-administration sessions. 

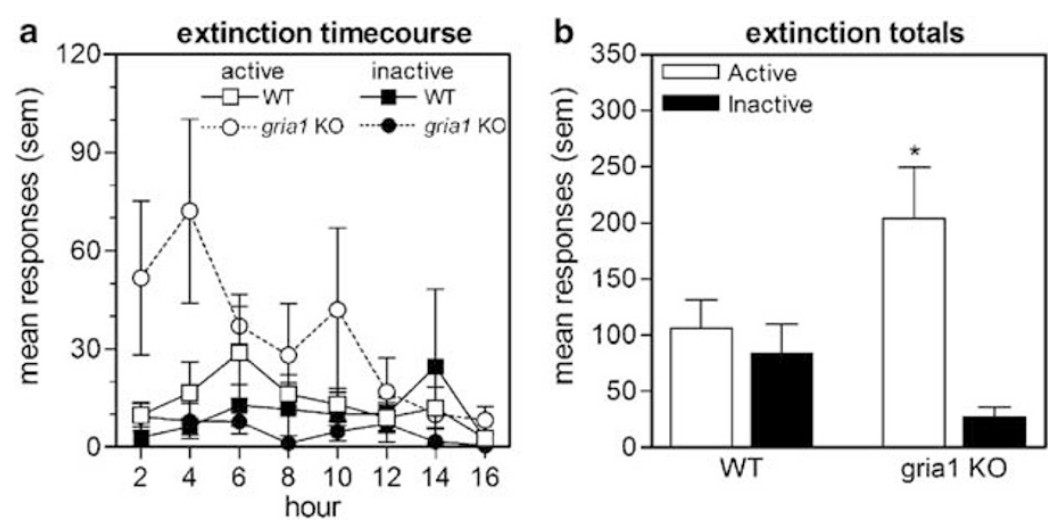

Figure 3 Extinction of lever pressing for cocaine in WT and grial $\mathrm{KO}$ mice. (a) Mean responses on the lever previously paired with cocaine infusions in WT (squares) and grial $\mathrm{KO}$ (circles) mice during the first $16 \mathrm{~h}$ of the extinction session. (b) Mean total responses on the active lever in WT and gria I KO mice during the 17-h extinction session. $* 0$ $<0.05$ compared to WT active.
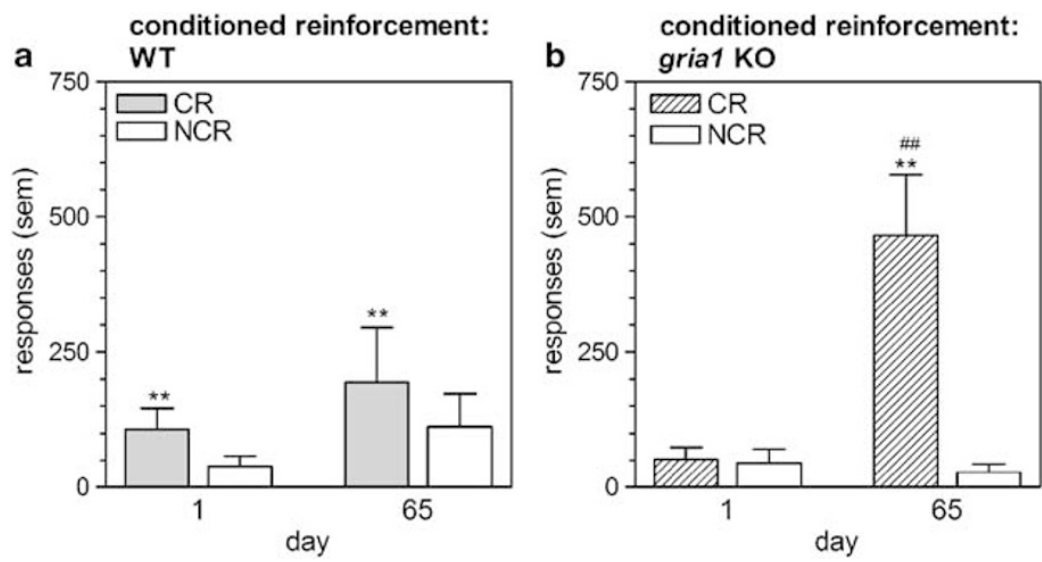

Figure 4 Responding for a cocaine-paired cue (CR) in WT and grial KO mice. (a) Responses into a nose-poke aperture for presentation of the cocainepaired cue (CR) and into a control nose-poke aperture (NCR) in WT mice during a I5-h session. (b) Responses into a nose-poke aperture for presentation of the cocaine-paired cue (CR) and into a control nose-poke aperture (NCR) in grial KO mice during a I5-h session. ** $p<0.0$ I compared to NCR. $\# \#<0.0$ I compared to day I CR.

into a control aperture, indicating that the CS had acquired conditioned reinforcing properties as a result of its prior association with cocaine (Figure $4 \mathrm{a}$, main-effect of aperture; $\left.\mathrm{F}_{1,5}=51.1, p<0.001\right)$. The duration of the withdrawal period did not influence response rates for the CS in WT mice, as indicated by a lack of main-effect of withdrawal period or a withdrawal period by aperture interaction $\left(\mathrm{F}_{1,5}=0.60\right.$ and $\mathrm{F}_{1,5}=0.20$, respectively). In contrast, gria1 $\mathrm{KO}$ mice failed to display selective responding for the CS when tested one day after the final cocaine self-administration session (short withdrawal), but showed clear responding for the CS when tested after 65 days (extended withdrawal), giving rise to a significant interaction between aperture, genotype and withdrawal period $\left(\mathrm{F}_{1,11}=17.4\right.$, $p<0.001$ ) (Figure $4 \mathrm{~b}$, aperture by withdrawal period interaction; $\left.F_{1,6}=22.1, p<0.001\right)$. These data suggest that GluR1-containing AMPA receptors may play a necessary role in the attribution of motivational value to cues during the initial stages of cocaine withdrawal, but may play an inhibitory role in the same process following extended withdrawal.

\section{Spontaneous and Cue-Induced Reinstatement}

When mice were re-introduced into the operant chambers (with the levers present) on day 66, both WT and gria1 KO mice displayed spontaneous reinstatement of lever pressing, however, the magnitude of the spontaneous reinstatement was greater in gria1 KO mice than in WT mice (Figure 5, withdrawal period by genotype interaction; $\mathrm{F}_{1,12}=10.16$, $p<0.01)$. This effect was apparent despite the fact that levels of responding did not differ between genotypes during extinction, or during the test for spontaneous reinstatement on day 3. Thus, it appears that at short withdrawal periods, following extinction, GluR1 may play an inhibitory role in cocaine-seeking behavior, in keeping with Self's hypothesis that heightened expression of GluR1 during extinction is necessary for suppression of previously-rewarded behavior (Self et al, 2004).

A similar pattern of results was obtained when the ability of the cocaine-paired cue to reinstate lever-pressing (cocaine-seeking) behavior was examined. When tested on day 3 (short withdrawal), WT and gria1 KO mice displayed 

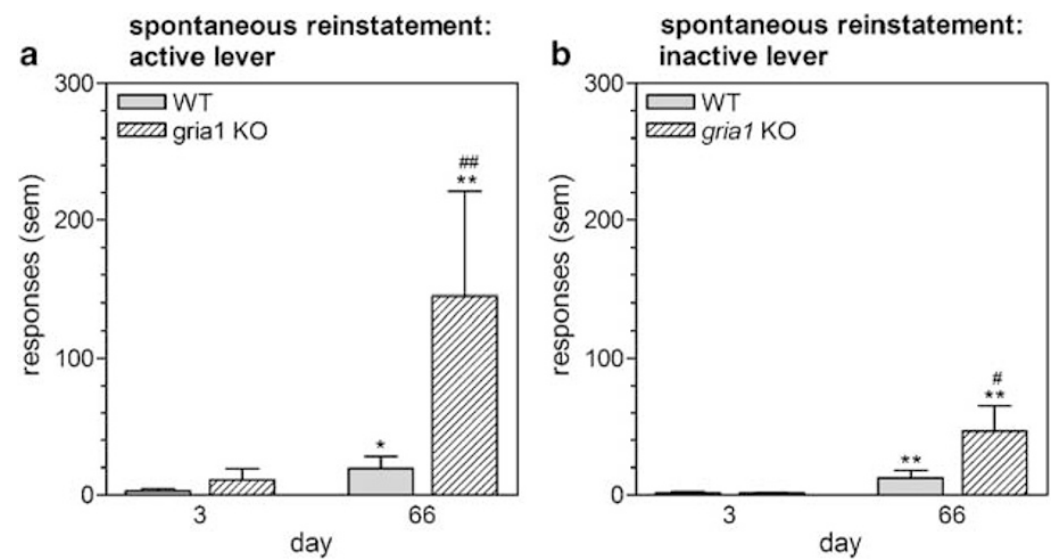

Figure 5 (a) Spontaneous reinstatement of cocaine seeking in WT and grial $\mathrm{KO}$ mice. Responses on the lever previously paired with cocaine infusions in WT (filled bars) and grial KO (open bars) mice during a 3-h session. (b) Responses on the control lever in WT (filled bars) and gria I KO (open bars) mice during a 3-h session. ${ }^{*} p<0.05,{ }^{*} p<0.0$ l compared to day $3 .{ }^{\#} p<0.05,{ }^{\# \#} p<0.0$ I compared to WT.

similar patterns of responding during both the baseline period and when the CS was made available. Both groups displayed enhanced responding on the active lever when the CS was introduced, indicating cue-induced facilitation of cocaine-seeking; no effect of the CS was observed on responding on the inactive lever (Figure 6, CS by lever interaction; $\left.F_{1,11}=84.9, p<0.001\right)$. Following extended withdrawal on day 66, both WT and grial KO mice displayed an enhancement in responding on the active lever following the introduction of the CS, compared with response rates on day 3 (CS by lever by withdrawal period interaction; $\left.\mathrm{F}_{1,11}=30.5, p<0.001\right)$. However, gria1 KO mice also displayed enhanced responding during the baseline period, consistent with the effects seen with spontaneous reinstatement $\left(t_{6}=3.77, p<0.01\right)$; in WT mice, no such increase was observed. As reported by others ( $\mathrm{Lu}$ and Dempsey 2004), a small increase in inactive lever responses following extended withdrawal was also observed in both WT and gria1 KO mice, but this did not reach significance (main-effect of withdrawal period for inactive lever responses; $\mathrm{F}_{1,5}=4.5$ and $\mathrm{F}_{1,6}=5.8$, respectively, NS).

\section{CR and Cue-Induced Reinstatement for a Food-Paired Cue}

Both gria1 KO and WT mice successfully acquired responding for food-pellets, as evidenced by a significant lever by session interaction (Figure $7 \mathrm{a}, \mathrm{F}_{14,420}=18.8$, $p<0.001)$. A three-way session by lever by genotype interaction indicated that during the acquisition of this response, there were differences between WT and gria1 KO mice. Subsequent analysis revealed that gria1 KO mice responded at a faster rate than WT mice on the active lever during sessions 3,7 and $8 \quad(p<0.05)$. However, once responding had reached asymptote, no between-genotype differences were observed, suggesting that this difference reflected a subtle difference in acquisition rates.

Analysis of response rates into the nose-poke detectors during the $\mathrm{CR}$ test revealed that both WT and gria1 $\mathrm{KO}$ mice acquired responding for $\mathrm{CR}$ to a comparable degree (Figure $7 \mathrm{~b}, \mathrm{~F}_{1,27}=20.3, p<0.001$ ). In addition, grial
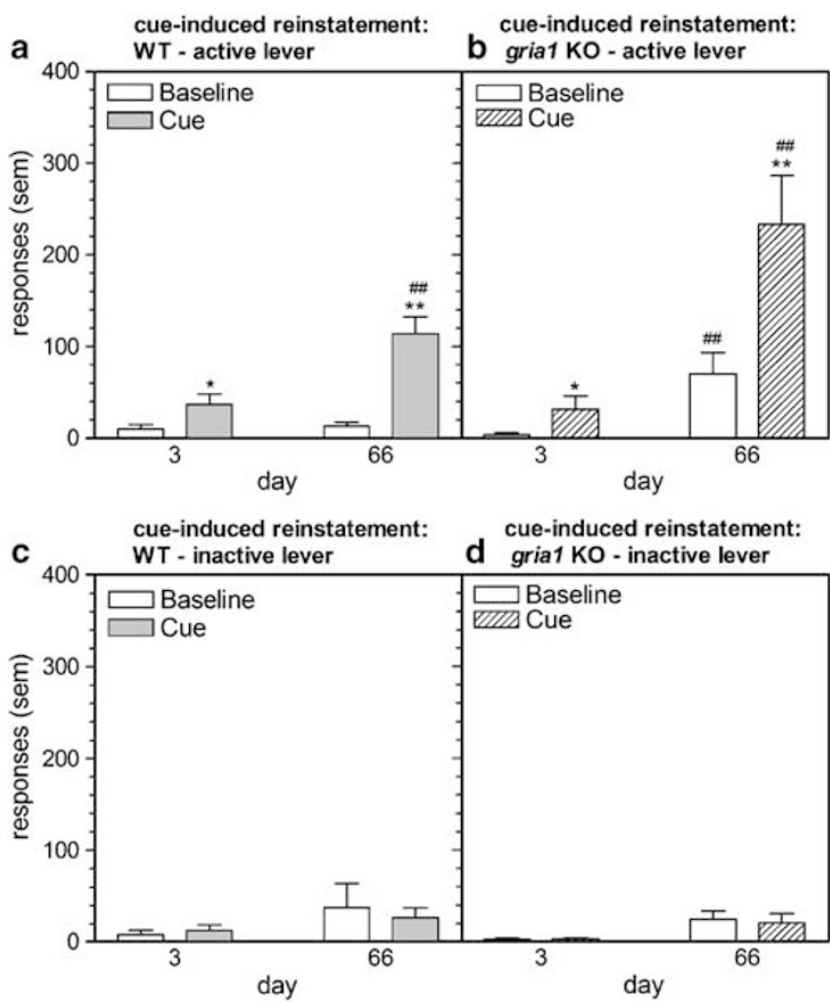

Figure 6 Cue-induced reinstatement of cocaine seeking in WT and gria I $\mathrm{KO}$ mice. ( $\mathrm{a}, \mathrm{b})$ Responses on the lever previously paired with cocaine infusions in WT and grial $\mathrm{KO}$ mice during a 3-h baseline period (open bars) followed by a 3-h cue period (filled bars). (c, d) Responses on the control lever in WT and grial $\mathrm{KO}$ mice during a 3-h baseline period followed by a 3-h cue period. ${ }^{*} p<0.05$, $* * p<0.01$ compared to baseline. $\#$ \# $<0.01$ compared to day 3 .

KO mice responded at a faster rate in both detectors (main-effect of genotype; $\mathrm{F}_{1,27}=5.86, \quad p<0.05$ ). This finding is consistent with increased exploratory activity in the $\mathrm{KO}$ mice, rather than increased responding for $\mathrm{CR}$, since the increased rate was observed in both $\mathrm{CR}$ and NCR detectors. 


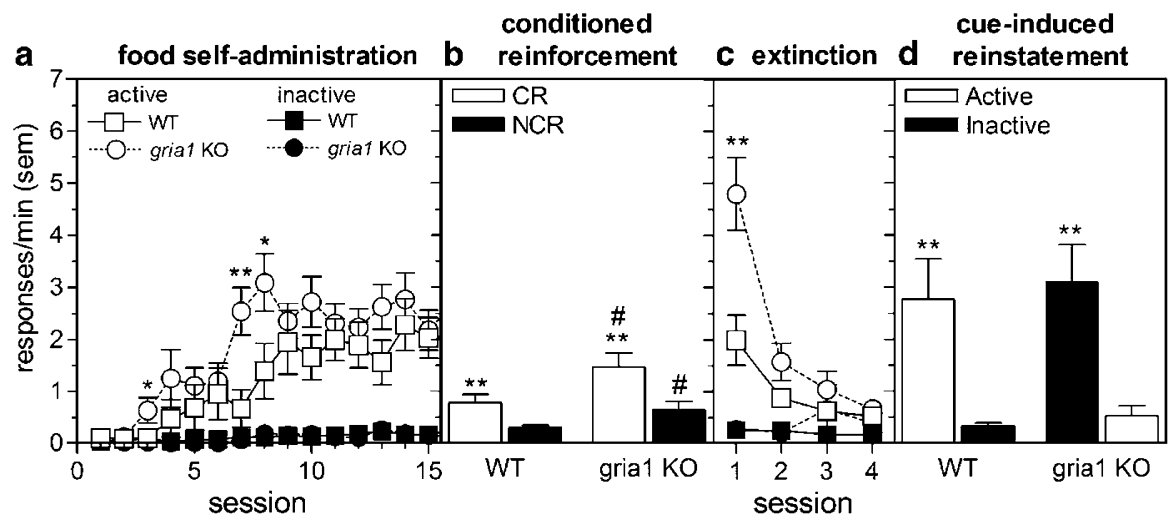

Figure 7 CR and cue-induced reinstatement of food seeking in WT and grial KO mice. (a) Mean lever response rates for food-pellets during daily 60 -min sessions in WT (squares) and grial KO (circles) mice. $* p<0.05$, ** $p<0.01$ compared to WT active. (b) Mean nose-poke response rates for a food-paired conditioned stimulus during a 60-min session. Responses in the CR aperture resulted in a brief presentation of the CS, while responses in the NCR aperture were without effect. ${ }^{*} * p<0.01$ compared to NCR, ${ }^{\#} p<0.05$ compared to WT. (c) Mean lever response rates during four daily 60-min extinction sessions. No cues were presented during these sessions. $* *$ $p<0.0$ I compared to WT. (d) Mean lever response rates during a 60-min reinstatement session, during which responses on the active lever resulted in presentation of the food-paired CS. $* * * 0.01$ compared to extinction session 4.

Analysis of responding during extinction of the operant lever response (Figure 7c), indicated that both WT and grial $\mathrm{KO}$ mice displayed rapid extinction of the behavior (session by lever interaction; $\mathrm{F}_{3,78}=23.6, p<0.001$ ). A significant three-way interaction (genotype by session by lever; $\mathrm{F}_{3,78}=6.4, p<0.001$ ) was further examined, and revealed that grial KO mice responded at a faster rate during the first extinction session $\left(t_{26}=3.21, p<0.01\right)$. No between genotype differences were observed during the remaining extinction sessions.

Following the reintroduction of the cue, three-way ANOVA revealed a significant session by lever interaction $\left(\mathrm{F}_{1,26}=20.0, p<0.001\right)$, indicating that the food-paired CS reinstated food-seeking, as manifest by a selective increase in responding on the active lever, compared to the final extinction session (Figure 7d). A lack of significant genotype effects indicated that cue-induced reinstatement was comparable across genotypes.

\section{DISCUSSION}

The first important finding of these studies was that, although GluR1 subunits of AMPA receptors have been implicated in plastic responses to cocaine (Ghasemzadeh et al, 2003), there was no indication in the present study that self-administration of cocaine was altered in GluR1 KO mice. This observation is consistent with our previous reports that the KO does not impair instrumental responding for a natural reward (Mead and Stephens 2003), or the development of a conditioned place preference for cocaine (Mead et al, 2005) and that pharmacological antagonists of AMPA receptors have little effect on cocaine self-administration (Jackson et al, 1998). However, recent studies have implied a role for GluR1 in cocaine's reinforcing effects, with virally mediated overexpression of GluR1 increasing the break point for cocaine under a progressive ratio schedule (Choi et al, 2003), and deletion of grial preventing the formation of a conditioned place preference to cocaine (Dong et al, 2004). There is no clear way to integrate the present findings with these previous studies, though it should be noted that overexpression of GluR1 was selective for the VTA (Choi et al, 2003), raising the possibility that in the KO model, altered GluR1 expression in additional regions, may play a role in cocaine's reinforcing efficacy. Additionally, it cannot be excluded that in mice with constitutive deletion of GluR1 that other processes may take over the function normally carried out by this subunit. The two place conditioning studies are also difficult to compare directly, since the design of these studies differed in a number of ways (for example, dose selection, dosing regime and biased vs unbiased design). Clearly, further work is needed to understand how GluR1-containing AMPAreceptors play a role in mediating the reinforcing effects of cocaine.

The second significant finding from this study was that grial deletion resulted in increased extinction responding for food reward, and a trend towards increased extinction responding during the initial stages of the session for cocaine reward. This trend was significant when responding over the entire 17-h extinction session was analyzed. Previous reports have shown that extinction of responding for intravenous self-administered cocaine is associated with increased expression of GluR1 subunits in the shell of the accumbens (Self et al, 2004; Tang et al, 2004), and overexpression of GluR1 in accumbens following virallymediated gene transfer facilitates extinction (Self et al, 2004). Thus, increased expression of GluR1 subunits appears to facilitate extinction learning, and accordingly the absence of GluR1 impairs extinction learning. Interestingly, overexpression of GluR1 in the accumbens did not affect extinction of a sucrose-reinforced response (Sutton et al, 2003), and the delayed extinction seen in the current study with sucrose pellets suggests that the effects of gene $\mathrm{KO}$ and transient localized gene overexpression are not simply opposite to each other.

Using the cue-induced reinstatement model (See, 2002), we further found that while, following extinction of the instrumental response, a cocaine-associated cue reinstated drug-seeking behavior in mice, there was no difference 
between KO and WT mice in this respect. Given that the basolateral subregion of the amygdala (BLA) is known to be involved in mediating cue-induced reinstatement of drug seeking (Kruzich and See, 2001), and the phenotype of the gria1 KO mouse resembles that of rats with BLA lesions (Mead and Stephens, 2003), this result is somewhat surprising. We have previously reported that the grial $\mathrm{KO}$ mouse displays a similar phenotype to that observed following lesions of the BLA, based on findings from stimulus-reward learning based tasks (Mead and Stephens, 2003). However, we now know this parallel does not extend to all forms of reward-based learning, given the results obtained with both conditioned place preference (Mead et al, 2005) and cue-induced reinstatement models. These differences could reflect different amygdaloid pathways, output pathways, or altered neuronal functioning in regions separate from the amygdala. It is also interesting to note that while both systemic and intra-accumbal AMPAreceptor antagonism attenuate cue-induced reinstatement of cocaine seeking (Backstrom and Hyytia, 2005; Cornish and Kalivas, 2000), and intra-accumbens AMPA agonism induces reinstatement of cocaine seeking (Cornish et al, 1999; Suto et al, 2004), intra-BLA infusion of an AMPAreceptor antagonist is without effect on cue-induced reinstatement (See et al, 2001). These findings imply that while the BLA plays an important role in the cue-induced reinstatement of cocaine seeking, this effect is not mediated via AMPA-receptors within the BLA, and instead it may be the neural outputs from this region, in particular to the nucleus accumbens, that are critical for mediating the reinstatement of cocaine seeking.

It has been suggested (Di Ciano and Everitt, 2004) that the extinction-reinstatement model depends upon the animal performing an instrumental response to obtain access to a cue conditioned to the primary reinforcer (Koob, 2000; Shalev et al, 2002), a well-known phenomenon termed CR (Robbins, 1978). In most studies of CR, the US is presented independently of the animal's behavior, and it was thus important to confirm that a CS paired with instrumentallydelivered cocaine reinforcement was also capable of acquiring conditioned reinforcing properties in WT mice, as occurs in rats (Di Ciano and Everitt, 2002). WT mice displayed clear responding for $\mathrm{CR}$, but targeted deletion of gria1 abolished the ability of a cue conditioned to selfadministered cocaine delivery to act as a conditioned reinforcer at short withdrawal periods, as has been demonstrated previously for experimenter-delivered food reward (Mead and Stephens, 2003). However, the findings from the parallel food-cue study suggest that the role of GluR1 in CR is also influenced by the nature of the original cue-reward association. When food-reward was obtained following an instrumental response, the associated cue was able to reinforce responding in gria1 $\mathrm{KO}$ mice. This is in contrast to our previous report, whereby gria1 KO mice did not respond for a cue that had attained significance during experimenter-administered reward (Mead and Stephens, 2003). Therefore, in the present study, restricted to instrumental cue-reward association formation, there appears to be a specific deficit in grial $\mathrm{KO}$ mice for a cocainepaired cue. The finding that a cue-reward association should differ in nature, when the association is formed during a self-administered procedure, as opposed to an experimenter administered procedure, is not surprising. In the latter case, during training the cue acts as a predictor of reward availability, and the animal must utilise this information to respond appropriately (ie collect the food pellet). In contrast, during the self-administration procedure, the cue provides no information predictive of reward delivery additional to that already provided by completion of the lever press, and according to learning theory should possess only weak associative strength. Presumably, then, when the cue is paired with reinforcer delivery following an instrumental response, the properties it acquires are not simply the result of Pavlovian association; perhaps it acts as a confirmatory signal of successful completion of the instrumental response.

The finding that the cue was able to support reinstatement behavior but not act as a conditioned reinforcer provides the first evidence that the reinstating, and conditioned reinforcing properties of the cue are dissociable. In addition to acting as conditioned reinforcers (where the animal performs an instrumental response to obtain the conditioned cue), Pavlovian cues conditioned to primary rewards also energise instrumental responding for the primary reinforcer (Pavlovian-to-instrumental transfer (Dickinson, 1994)); during reinstatement the CS is presented while the animal is performing an operant response in attempts to obtain the US - albeit at low levels following extinction, and cue presentation may thus energize further responding. Deletion of gria1 does not affect Pavlovian-toinstrumental transfer (Mead and Stephens, 2003), so that, in principle, in these experiments CS-induced 'reinstatement' may reflect this property (ie facilitation of responding) rather than $\mathrm{CR}$. While most laboratories studying cueinduced reinstatement present the cocaine-conditioned cue contingent upon an instrumental response (See, 2002; Shaham et al, 2003), cues conditioned to cocaine are able to reinstate responding following extinction even when their presentation is not contingent on the animal's behavior (ie under circumstances that they cannot be acting as conditioned reinforcers) (Alleweireldt et al, 2001; de Wit and Stewart, 1981; Deroche-Gamonet et al, 2002; Fuchs et al, 1998), this account seems plausible. However, it should also be noted that others have reported that non-contingent presentation of discrete cues does not result in reinstatement of drug seeking (Grimm et al, 2000; Tran-Nguyen et al, 1998), and further work is required to fully understand the requirement for operant contingency on reinstatement behavior. That gria1 deletion failed to affect cue-induced reinstatement of cocaine or food seeking suggests that GluR1-containing AMPA-receptors are not involved in the neurobiological pathways underlying cue-induced relapse behavior, consistent with a lack of effect on cue-induced reinstatement of the AMPA-antagonist CNQX infused into the basolateral amygdala (See et al, 2001) (despite this behavior being dependent upon basolateral amygdala function (Meil and See, 1997)). The basolateral amygdala is intimately linked with the nucleus accumbens, and virally-mediated overexpression of GluR1 in the accumbens shell is also without effect on cue-induced relapse to cocaine seeking (Sutton et al, 2003).

An alternative account of the different effects of gria1 deletion on cue-induced reinstatement and CR is suggested by the fact that the $\mathrm{CR}$ paradigm requires the animal to 
acquire a novel instrumental response to obtain the cue, whereas, in the reinstatement paradigm, the instrumental response required to obtain the cue is already trained. In that context, it is of interest that acquisition of instrumental responding, but not its performance may be prevented by disruption of amygdala transmission by a locally administered antagonist of D1 receptors (Andrzejewski et al, 2005). Perhaps incentives mediate instrumental learning by increasing dopamine activity in at D1 receptors in amygdala and related limbic regions accounting for the ability of psychostimulant drugs to rescue CR in rats with basolateral amygdala lesions (Everitt et al, 1989). While the GluR1 KO mice showed no deficits in acquisition of an instrumental response to obtain food or cocaine, the incentive value of a conditioned reinforcer is likely to be lower than food or cocaine On this account, GluR1-containing AMPA receptors are important in pathways that translate the incentive value of a reinforcer into learning of a new response (but see below).

Consistent with previous studies in rats (Grimm et al, 2001; Grimm et al, 2003), in WT mice an extended abstinence period, in which the animals did not have the opportunity to self-administer cocaine, resulted in incubation (Grimm et al, 2001), seen as increased ability of the cue to reinstate drug-seeking behavior in the cue-induced reinstatement paradigm (ie performance of the instrumental response that previously gave rise to cocaine). In contrast, the extended abstinence period did not affect the reinforcing value of the cue, as assessed using the CR test (requiring the performance of a novel instrumental response). These observations, too, suggest that $\mathrm{CR}$ and cue-induced reinstatement may be dissociable phenomena. The gria1 KO mice displayed a quite different response to abstinence; whereas the KO mice failed to respond for a cocaine-associated conditioned reinforcer following a short 24-h withdrawal period, following extended 65-day abstinence, KO mice displayed enhanced responding for the conditioned reinforcer compared to that seen in WT mice. Thus, while GluR1 subunits appear to be important in mediating the conditioned rewarding properties of cocaineassociated cues in the short term following abstinence from cocaine self-administration, the deficit induced by grial deletion was overcome during protracted abstinence, which thus appears to be independent of pathways using GluR1containing receptors. The finding of facilitation of responding for a conditioned reinforcer in the GluR1 KO at this delayed interval is difficult to reconcile with the idea that the differences seen in the $\mathrm{KO}$ in $\mathrm{CR}$ and cue-induced reinstatement are attributable to the former, but not the latter, requiring new instrumental learning. Interestingly, GluR1 expression in the nucleus accumbens is increased one day following withdrawal from cocaine self-administration, but returns to baseline 30 days following withdrawal (Lu et al, 2003), consistent with a time-dependent role for GluR1 in the neuroadaptations following cessation of cocaine self-administration. Time-dependent changes in GluR2 and NMDA glutamate-receptor subunits within both the accumbens and amygdala have also been reported following cessation of cocaine self-administration demonstrating that complex time-dependent changes occur within the glutamatergic system following a period of cocaine selfadministration (Lu et al, 2005; Lu et al, 2003).
In addition to the incubation of cue-induced reinstatement, we also observed spontaneous reinstatement of responding following protracted abstinence. Spontaneous reinstatement of responding following extinction does appear to be dependent on GluR1-containing AMPAreceptors: While both $\mathrm{WT}$ and grial $\mathrm{KO}$ mice displayed a significant increase in responding (relative to their last extinction session) following re-exposure to the selfadministration apparatus (context) following 66 days of withdrawal, the magnitude of this effect was significantly greater in the $\mathrm{KO}$ mice. In studies of extinction, it is commonly observed that interposing a delay between the extinction experience and reexposing the animal to the apparatus results in a spontaneous recovery of responding. This recovery may be attributable to relative 'forgetting' of the extinction experience (that usually involves relatively few pairings of the instrumental response with absence of reinforcement), so that the previously reinforced behavior (that was trained using many responsereinforcement pairings) is once again predominant in the presence of contextual reminder cues (Bouton, 1993; Bouton and Ricker, 1994; Brooks and Bouton, 1994). That the KO mice showed an enhanced spontaneous recovery may suggest that GluR1-containing AMPA-receptors have a contributory role to play in the ability of the extinction experience to suppress the previously rewarded behavior. Alternatively, they may mediate inhibitory control over motivation for cocaine (Self et al, 2004) induced by the context.

The experiments reported here, provide important data on two phenomena whose importance is relatively poorly understood in the context of drug abuse: firstly, the incubation of the ability of conditioned stimuli to influence behavior; and secondly the loss, following a delay, of the ability of a period of non-reinforced responding (extinction) to suppress instrumental behavior (spontaneous recovery). Our data suggest that GluR1-containing AMPA receptors may play a role in the latter, but not the former. In addition, we have demonstrated that GluR1 is not required for normal self-administration of cocaine or food, implying that receptors containing this subunit are not critical for mediating instrumental reward. The comparison between experimenter and self-administered reward has highlighted the complexity of the cuereward association, and the importance of training methodology in determining the contribution of specific AMPAreceptor subunits, and further work is clearly necessary to fully understand this relationship. Finally, the dissociation between $C R$ and cue-induced reinstatement provides the first demonstration that cue-induced reinstatement behavior reflects more than simply responding for $\mathrm{CR}$, as often assumed. Investigating these behaviors further should aid our understanding of the neural mechanisms responsible for drug seeking behavior following exposure to drugpaired stimuli.

\section{ACKNOWLEDGEMENTS}

This work was supported by BBSRC Project Grant S14554. We thank Geraldine Brown and Stuart Rulten for genotyping, and Patricia Di Canio for helpful discussions. 


\section{REFERENCES}

Alleweireldt AT, Weber SM, Neisewander JL (2001). Passive exposure to a contextual discriminative stimulus reinstates cocaine-seeking behavior in rats. Pharmacol Biochem Behav 69: 555-560.

Andrzejewski ME, Spencer RC, Kelley AE (2005). Instrumental learning, but not performance, requires dopamine D1-receptor activation in the amygdala. Neuroscience 135: 335-345.

Backstrom P, Hyytia P (2005). Ionotropic and Metabotropic Glutamate Receptor Antagonism Attenuates Cue-Induced Cocaine Seeking. Neuropsychopharmacology [E-pub August 3, 2005 PMID: 16123768].

Bossert JM, Ghitza UE, Lu L, Epstein DH, Shaham Y (2005). Neurobiology of relapse to heroin and cocaine seeking: An update and clinical implications. Eur J Pharmacol 526: 36-50.

Boudreau AC, Wolf ME (2005). Behavioral sensitization to cocaine is associated with increased AMPA receptor surface expression in the nucleus accumbens. J Neurosci 25: 9144-9151.

Bouton ME (1993). Context, time, and memory retrieval in the interference paradigms of Pavlovian learning. Psychol Bull 114: 80-99.

Bouton ME, Ricker ST (1994). Renewal of extinguished responding in a second context. Animal Learn Behav 22: 317-324.

Brooks DC, Bouton ME (1994). A retrieval cue for extinction attenuates spontaneous recovery. J Exp Psychol: Animal Behav Process 19: 77-89.

Choi KH, Rahman Z, Edwards S, Hall S, Neve RL, Self DW (2003). Opposite effects of GluR1 and PKA-resistant GluR1 overexpression in the ventral tegmental area on cocaine reinforcement. Ann NY Acad Sci 1003: 372-374.

Churchill L, Swanson CJ, Urbina M, Kalivas PW (1999). Repeated cocaine alters glutamate receptor subunit levels in the nucleus accumbens and ventral tegmental area of rats that develop behavioral sensitization. J Neurochem 72: 2397-2403.

Cornish JL, Duffy P, Kalivas PW (1999). A role for nucleus accumbens glutamate transmission in the relapse to cocaineseeking behavior. Neuroscience 93: 1359-1367.

Cornish JL, Kalivas PW (2000). Glutamate transmission in the nucleus accumbens mediates relapse in cocaine addiction. J Neurosci 20: RC89.

Deroche-Gamonet V, Piat F, Le Moal M, Piazza PV (2002). Influence of cue-conditioning on acquisition, maintenance and relapse of cocaine intravenous self-administration. Eur J Neurosci 15: 1363-1370.

de Wit H, Stewart J (1981). Reinstatement of cocaine-reinforced responding in the rat. Psychopharmacology (Berlin) 75: 134-143.

Di Ciano P, Everitt BJ (2002). Reinstatement and spontaneous recovery of cocaine-seeking following extinction and different durations of withdrawal. Behav Pharmacol 13: 397-405.

Di Ciano P, Everitt BJ (2004). Conditioned reinforcing properties of stimuli paired with self-administered cocaine, heroin or sucrose: implications for the persistence of addictive behaviour. Neuropharmacology 47(Suppl 1): 202-213.

Dickinson A (1994). Instrumental conditioning. In: Mackintosh $\mathrm{N}$ (ed) Animal Learning and Cognition. Academic Press: London. pp. 45-78.

Dong Y, Saal D, Thomas M, Faust R, Bonci A, Robinson T et al (2004). Cocaine-induced potentiation of synaptic strength in dopamine neurons: behavioral correlates in GluRA(-I-) mice. Proc Natl Acad Sci USA 101: 14282-14287.

Everitt BJ, Cador M, Robbins TW (1989). Interactions between the amygdala and ventral striatum in stimulus-reward associations: studies using a second-order schedule of sexual reinforcement. Neuroscience 30: 63-75.

Fitzgerald LW, Ortiz J, Hamedani AG, Nestler EJ (1996). Drugs of abuse and stress increase the expression of GluR1 and NMDAR1 glutamate receptor subunits in the rat ventral tegmental area: common adaptations among cross-sensitizing agents. J Neurosci 16: $274-282$.

Fuchs RA, Tran-Nguyen LT, Specio SE, Groff RS, Neisewander JL (1998). Predictivevalidity of the extinction/reinstatement model of drug craving. Psychopharmacology 135: 151-160.

Gawin FH, Kleber HD (1986). Abstinence symptomatology and psychiatric diagnosis in cocaine abusers. Clinical observations. Arch Gen Psychiatry 43: 107-113.

Ghasemzadeh MB, Permenter LK, Lake R, Worley PF, Kalivas PW (2003). Homer1 proteins and AMPA receptors modulate cocaine-induced behavioural plasticity. Eur J Neurosci 18: $1645-1651$.

Grignaschi G, Burbassi S, Zennaro E, Bendotti C, Cervo L (2004). A single high dose of cocaine induces behavioural sensitization and modifies mRNA encoding GluR1 and GAP-43 in rats. Eur J Neurosci 20: 2833-2837.

Grimm JW, Hope BT, Wise RA, Shaham Y (2001). Neuroadaptation. Incubation of cocaine craving after withdrawal. Nature 412: 141-142.

Grimm JW, Kruzich PJ, See RE (2000). Contingent access to stimuli associated with cocaine self-administration is required for reinstatement of drug-seeking behavior. Psychobiology 28: 383-386.

Grimm JW, Lu L, Hayashi T, Hope BT, Su TP, Shaham Y (2003). Time-dependent increases in brain-derived neurotrophic factor protein levels within the mesolimbic dopamine system after withdrawal from cocaine: implications for incubation of cocaine craving. J Neurosci 23: 742-747.

Highfield DA, Mead AN, Grimm JW, Rocha BA, Shaham Y (2002). Reinstatement of cocaine seeking in 129X1/SvJ mice: effects of cocaine priming, cocaine cues and food deprivation. Psychopharmacology (Berlin) 161: 417-424.

Jackson A, Mead AN, Rocha BA, Stephens DN (1998). AMPA receptors and motivation for drug: effect of the selective antagonist NBQX on behavioural sensitization and on selfadministration in mice. Behav Pharmacol 9: 457-467.

Kalivas PW, McFarland K (2003). Brain circuitry and the reinstatement of cocaine-seeking behavior. Psychopharmacology 168: $44-56$.

Koob GF (2000). Animal models of craving for ethanol. Addiction 95(Suppl 2): S73-S81.

Kruzich PJ, See RE (2001). Differential contributions of the basolateral and central amygdala in the acquisition and expression of conditioned relapse to cocaine-seeking behavior. J Neurosci 21: RC155.

Lu L, Dempsey J (2004). Cocaine seeking over extended withdrawal periods in rats: time dependent increases of responding induced by heroin priming over the first 3 months. Psychopharmacology (Berlin) 176: 109-114.

Lu L, Dempsey J, Shaham Y, Hope BT (2005). Differential longterm neuroadaptations of glutamate receptors in the basolateral and central amygdala after withdrawal from cocaine selfadministration in rats. J Neurochem 94: 161-168.

Lu L, Grimm JW, Shaham Y, Hope BT (2003). Molecular neuroadaptations in the accumbens and ventral tegmental area during the first 90 days of forced abstinence from cocaine selfadministration in rats. J Neurochem 85: 1604-1613.

Malinow R, Malenka RC (2002). AMPA receptor trafficking and synaptic plasticity. Annu Rev Neurosci 25: 103-126.

Mangiavacchi S, Wolf ME (2004). D1 dopamine receptor stimulation increases the rate of AMPA receptor insertion onto the surface of cultured nucleus accumbens neurons through a pathway dependent on protein kinase A. J Neurochem 88: 1261-1271.

Mead AN, Brown G, Le Merrer J, Stephens DN (2005). Effects of deletion of gria1 or gria2 genes encoding glutamatergic AMPAreceptor subunits on place preference conditioning in mice. Psychopharmacology (Berlin) 179: 164-171. 
Mead AN, Stephens DN (2003). Selective disruption of stimulusreward learning in glutamate receptor grial knock-out mice. J Neurosci 23: 1041-1048.

Meil WM, See RE (1997). Lesions of the basolateral amygdala abolish the ability of drug associated cues to reinstate responding during withdrawal from self-administered cocaine. Behav Brain Res 87: 139-148.

Pierce RC, Bell K, Duffy P, Kalivas PW (1996). Repeated cocaine augments excitatory amino acid transmission in the nucleus accumbens only in rats having developed behavioral sensitization. J Neurosci 16: 1550-1560.

Robbins TW (1978). The acquisition of responding with conditioned reinforcement: effects of pipradrol, methylphenidate, d-amphetamine, and nomifensine. Psychopharmacology (Berlin) 58: 79-87.

See RE (2002). Neural substrates of conditioned-cued relapse to drug-seeking behavior. Pharmacol Biochem Behav 71: 517-529.

See RE, Fuchs RA, Ledford CC, McLaughlin J (2003). Drug addiction, relapse, and the amygdala. Ann NY Acad Sci 985: 294-307.

See RE, Kruzich PJ, Grimm JW (2001). Dopamine, but not glutamate, receptor blockade in the basolateral amygdala attenuates conditioned reward in a rat model of relapse to cocaine-seeking behavior. Psychopharmacology (Berlin) 154: 301-310.

Self DW, Choi KH, Simmons D, Walker JR, Smagula CS (2004). Extinction training regulates neuroadaptive responses to withdrawal from chronic cocaine self-administration. Learn Mem 11: 648-657.

Shaham Y, Shalev U, Lu L, De Wit H, Stewart J (2003). The reinstatement model of drug relapse: history, methodology and major findings. Psychopharmacology (Berlin) 168: 3-20.

Shalev U, Grimm JW, Shaham Y (2002). Neurobiology of relapse to heroin and cocaine seeking: a review. Pharmacol Rev 54: 1-42.

Sun X, Zhao Y, Wolf ME (2005). Dopamine receptor stimulation modulates AMPA receptor synaptic insertion in prefrontal cortex neurons. J Neurosci 25: 7342-7351.

Suto N, Tanabe LM, Austin JD, Creekmore E, Pham CT, Vezina P (2004). Previous exposure to psychostimulants enhances the reinstatement of cocaine seeking by nucleus accumbens AMPA. Neuropsychopharmacology 29: 2149-2159.

Sutton MA, Schmidt EF, Choi KH, Schad CA, Whisler K, Simmons D et al (2003). Extinction-induced upregulation in AMPA receptors reduces cocaine-seeking behaviour. Nature 421: 70-75.

Tang W, Wesley M, Freeman WM, Liang B, Hemby SE (2004). Alterations in ionotropic glutamate receptor subunits during binge cocaine self-administration and withdrawal in rats. J Neurochem 89: 1021-1033.

Tran-Nguyen LT, Fuchs RA, Coffey GP, Baker DA, O'Dell LE, Neisewander JL (1998). Time-dependent changes in cocaineseeking behavior and extracellular dopamine levels in the amygdala during cocaine withdrawal. Neuropsychopharmacology 19: $48-59$.

Ungless MA, Whistler JL, Malenka RC, Bonci A (2001). Single cocaine exposure in vivo induces long-term potentiation in dopamine neurons. Nature 411: 583-587.

Zamanillo D, Sprengel R, Hvalby O, Jensen V, Burnashev N, Rozov A et al (1999). Importance of AMPA receptors for hippocampal synaptic plasticity but not for spatial learning. Science 284: $1805-1811$. 